\title{
PENINGKATAN PENGETAHUAN DAN KETRAMPILAN TENTANG PENDIDIKAN SEKSUAL SEJAK DINI PADA ANAK MELALUI PROGRAM UNDERWEAR RULES
}

\author{
Increasing Knowledge And Skills On Sexual Education \\ Of early Childhood Programs Through \\ Underwear Rules \\ Indriana Noor Istiqomah ${ }^{1}$, Laili Nur Azizah ${ }^{2}$, Dwi Ochta Pebriyanti ${ }^{3}$ \\ ${ }^{1,2,3}$ Prodi D3 Keperawatan Kampus Lumajang \\ Fakultas Keperawatan, Universitas Jember \\ J1. Brigjend Katamso Lumajang 67312 \\ email: indrinoor@unej.ac.id
}

\begin{abstract}
ABSTRAK
Fenomena kekerasan seksual terhadap anak semakin sering terjadi hampir di berbagai negara, dan terus meningkat dari waktu ke waktu, tidak hanya dari segi kuantitas bahkan juga kualitas. Tidak sedikit pula pelakunya adalah orang yang memiliki dominasi atas korban dan yang lebih tragis lagi pelakunya berasal dari lingkungan keluarga atau lingkungan sekitar anak berada, antara lain di dalam rumahnya sendiri, sekolah, lembaga pendidikan, dan lingkungan sosial anak. Kemampuan pelaku menguasai korban, baik dengan tipu daya maupun ancaman dan kekerasan, menyebabkan kejahatan ini sulit dihindari. Tindakan kekerasan seksual pada anak membawa dampak emosional dan fisik kepada korbannya. Untuk itu kita diharapkan mampu melakukan pencegahan agar tidak ada lagi kekerasan seksual pada anak, dengan cara memberikan pendidikan pengetahuan dan ketrampilan tentang pendidikan seksual sejak dini pada anak.

Tujuan kegiatan ini adalah meningkatkan pengetahuan dan ketrampilan tentang pendidikan seksual sejak dini pada anak melalui Program Underwear Rules di lingkungan TPQ Al Ihsan RW 27 Kelurahan Tompokersan, Kabupaten Lumajang. Sedangkan manfaat kegiatan ini adalah meningkatkan pengetahuan dan ketrampilan anak serta membantu orang tua menjelaskan pendidikan seks kepada anak di mana orang lain tidak bisa mencoba untuk menyentuh mereka, bagaimana bereaksi dan bagaimana untuk mencari bantuan.

Metode kegiatan dilakukan dengan tahapan sebagai berikut: 1) Penyampaian materi kepada anak TPQ tentang underwear rules dan senam underwear rules, serta simulasi praktek senam underwear rules menggunakan media video; 2) Praktik; 3) Evaluasi hasil pelaksanaan.

Hasil dari kegiatan ini adalah pengetahuan anak TPQ tentang underwear rules sebelum pemberian materi dan praktik kurang tetapi setelah diberi materi dan praktik menjadi cukup. Tindak lanjut yang perlu dilakukan adalah adanya kegiatan sejenis secara berkala pada masyarakat sekitar, dengan cakupan yang lebih luas (misalnya dengan sasaran pada pengajian ibu PKK, dan sejenisnya). Pada kegiatan pengabdian selanjutnya disarankan lebih banyak mempraktikkan isi materi sehingga materi yang disampaikan dapat selalu diingat.
\end{abstract}

Kata kunci: pendidikan seksual, anak, underwear rules

\section{ABSTRACT}

The phenomenon of sexual violence against children are becoming more frequent in various countries, and continues to increase over time in quantity even of quality. Not a few perpetrators are people who have dominance over the victim and the more tragic the culprit came from the family or the neighborhood children are, among other things in his own home, schools, educational institutions, and social environment of children. Perpetrators ability to master the victim, either by trickery or threats and violence, causing crime is hard to avoid. Sexual assault on a child carries the emotional and physical impact to the victim. For that we are expected to take precautions so that no sexual assault on a child again.

The purpose of this activity is to increase knowledge and skills about sexual education from early childhood through Underwear Rules Program in the TPQ Al Ihsan RW 27 Tompokersan, Lumajang. While 
the benefits of this activity is to increase the knowledge and skills of children and help parents explain to children about sex education where others can not try to touch them, how to react and how to seek help.

Method of activities carried out in stages as follows: 1) give education about underwear rules to children in the TPQ, practice simulation of underwear rules exercise using vide;2) Practice; 4) Evaluation of the results of the activity.

The results of these activities is the child's knowledge about underwear TPQ rules before education less but after being given the materials and practices be enough. Follow-up needs to be done is the kind of regular activity on the surrounding community, with wider coverage (eg with PKK, recitation grup, etc). At the next activities suggested more practice the content of the material so that the material presented can always remember.

Keywords: sexual education, child, underwear rules

\section{PENDAHULUAN}

Fenomena kekerasan seksual terhadap anak semakin sering terjadi dan menjadi global hampir di berbagai negara. Kasus kekerasan seksual terhadap anak terus meningkat dari waktu ke waktu. Peningkatan tersebut tidak hanya dari segi kuantitas atau jumlah kasus yang terjadi, bahkan juga dari kualitas.

Menurut Komisi Perlindungan Anak Indonesia (KPAI) pada tahun 2011 saja telah terjadi 2.275 kasus kekerasan terhadap anak, 887 kasus diantaranya merupakan kekerasan seksual anak. Pada tahun 2012 kekerasan terhadap anak telah terjadi 3.871 kasus, 1.028 kasus diantaranya merupakan kekerasan seksual terhadap anak. Tahun 2013, dari 2.637 kekerasan terhadap anak, 48 persennya atau sekitar 1.266 merupakan kekerasan seksual pada anak.

Anak menjadi kelompok yang sangat rentan terhadap kekerasan seksual karena anak selalu diposisikan sebagai sosok lemah atau yang tidak berdaya dan memiliki ketergantungan yang tinggi dengan orangorang dewasa di sekitarnya. Hal inilah yang membuat anak tidak berdaya saat diancam untuk tidak memberitahukan apa yang dialaminya.

Tidak sedikit pula pelakunya adalah orang yang memiliki dominasi atas korban dan yang lebih tragis lagi pelakunya adalah kebanyakan dari lingkungan keluarga atau lingkungan sekitar anak itu berada, antara lain di dalam rumahnya sendiri, sekolah, lembaga pendidikan, dan lingkungan sosial anak.Tidak ada satupun karakteristik khusus atau tipe kepribadian yang dapat diidentifikasi dari seorang pelaku kekerasan seksual terhadap anak. Dengan kata lain, siapa pun dapat menjadi pelaku kekerasan seksual terhadap anak atau pedofilia.
Kemampuan pelaku menguasai korban, baik dengan tipu daya maupun ancaman dan kekerasan, menyebabkan kejahatan ini sulit dihindari. Dari seluruh kasus kekerasan seksual pada anak baru terungkap setelah peristiwa itu terjadi, dan tak sedikit yang berdampak fatal.

KPAI mengatakan, kejahatan seksual terhadap anak-anak adalah bencana nasional bagi bangsa Indonesia. Saat ini, kejahatan seksual telah dikategorikan sebagai kejahatan luar biasa. Kejahatan seksual akan merusak generasi penerus bangsa karena adanya kecenderungan dari korban untuk menjadi pelaku saat mereka dewasa.

Tindakan kekerasan seksual pada anak membawa dampak emosional dan fisik kepada korbannya. Secara emosional, anak sebagai korban kekerasan seksual mengalami stress, depresi, goncangan jiwa, adanya perasaan bersalah dan menyalahkan diri sendiri, rasa takut berhubungan dengan orang lain, bayangan kejadian dimana anak menerima kekerasan seksual, mimpi buruk, insomnia, ketakutan dengan hal yang berhubungan dengan penyalahgunaan termasuk benda, bau, tempat, kunjungan dokter, masalah harga diri, disfungsi seksual, sakit kronis, kecanduan, keinginan bunuh diri, keluhan somatik, dan kehamilan yang tidak diinginkan.

Kekerasan seksual terhadap anak dapat terjadi kapan saja dan di mana saja. Siapa pun bisa menjadi pelaku kekerasan seksual terhadap anak. Pedofilia tidak pernah berhenti, pelaku kekerasan seksual terhadap anak juga cenderung memodifikasi target yang beragam, dan siapa pun bisa menjadi target kekerasan seksual, bahkan anak ataupun saudaranya sendiri, itu sebabnya pelaku kekerasan seksual terhadap anak ini dapat dikatakan sebagai predator. Kekerasan 
seksual terhadap anak merupakan pelanggaran HAM berat dan harus diletakkan sebagai kejahatan luar biasa (extraordinary crime) karena dampak yang ditimbulkannya telah mengancam masa depan generasi bangsa. Kekerasan seksual pada anak dapat dicegah sejak dini dengan memberikan pendidikan dan pemahaman pada anak mengenai pendidikan seks dengan metode yang mudah dipahami oleh anak.

TPQ Al-Ikhsan RW. 27 Kelurahan Tompokersan, Lumajang adalah salah satu tempat pendidikan $\mathrm{Al}$ Quran yang mengasuh sekitar 30 anak usia dini. Masa usia dini sering dikatakan sebagai masa keemasan atau The Golden Age Moment. Usia 0 sampai dengan 8 tahun adalah masa informasi di sekitarnya juga diiringi dengan rasa ingin tahu yang sangat tinggi (Hurlock: 2006). Rasa ingin tahu yang sangat tinggi ditunjukkan anak dengan aktif bertanya tentang berbagai hal yang mereka temui, serta mencari tahu berbagai jawaban yang mereka inginkan dengan bereksplorasi. Pada usia 4-6 tahun dimana kemampuan anak menyerap informasi yang luar biasa dan rasa ingin tahu anak yang sangat tinggi tersebut seiring dengan perkembangan peran seks yang berkembang pesat (Pitkoff: 2008).

Pencegahan dan Perlindungan merupakan Tanggungjawab Orang Dewasa. Ketika anak-anak dilecehkan mereka merasa malu, bersalah dan takut. Orang dewasa harus menghindari menciptakan tabu seputar seksualitas, dan pastikan anak tahu kepada siapa harus beralih jika mereka khawatir,cemas atau sedih. Anak-anak mungkin merasa bahwa ada sesuatu yang salah. Orang dewasa harus menjadi perhatian dan menerima perasaan dan perilaku mereka. Mungkin ada banyak alasan mengapa seorang anak menolak kontak dengan orang dewasa lain atau dengan anak lain. Ini harus dihormati. anak-anak harus selalu merasa bahwa mereka dapat berbicara dengan orang tua mereka tentang masalah ini. Dengan memberikan pendidikan seksual sejak dini selain dapat meningkatkan pemahaman anak bahwa tubuhnya hanya miliknya juga dapat melindungi anak dari kemungkinan bahaya seksual.

Program underwear rules adalah panduan sederhana untuk membantu orang tua menjelaskan pendidikan seks kepada anak di mana orang lain tidak bisa mencoba untuk menyentuh mereka, bagaimana bereaksi dan bagaimana untuk mencari bantuan. Program underwear rules ini memiliki aturan sederhana dimana anak tidak boleh disentuh oleh orang lain pada bagian tubuhnya yang ditutupi pakaian dalam (underwear) anak dan anak tidak boleh menyentuh bagian tubuh orang lain yang ditutupi oleh pakaian dalam. Hal ini juga membantu menjelaskan dengan metode yang mudah dipahami oleh anakanak bahwa tubuh mereka adalah milik mereka,bahwa ada rahasia yang baik dan buruk dan sentuhan yang baik dan buruk, dengan harapan anak sejak dini dapat dicegah dari perilaku kekerasan seksual.

\section{METODE}

Kegiatan pengabdian ini dilaksanakan di Musholla Al Ihsan bekerja sama dengan takmir Musholla Al Ihsan, pengurus RW 27 Kelurahan Tompokersan-Lumajang, guru dan santri TPQ Al Ihsan, serta mahasiswa Prodi D3 Keperawatan Unej. Metode yang digunakan dalam kegiatan ini adalah memberikan penyuluhan tentang materi underwear rules, materi senam underwear rules, dilanjutkan simulasi praktik senam underwear rules ("Sentuhan Boleh dan Setuhan Tidak Boleh") menggunakan media video yang dilakukan dalam waktu 1 hari. Evaluasi hasil kegiatan dilakukan satu bulan setelah pelaksanaan penyuluhan.

\section{HASIL}

Kegiatan pengabdian ini dilaksanakan di Musholla Al Ihsan RW 27, Kelurahan Tompokersan, Kecamatan Lumajang, Kabupaten Lumajang, bekerja sama dengan takmir Musholla Al Ihsan, diikuti oleh anak santri TPQ Al Ihsan RW 27 Kelurahan Tompokersan Kecamatan Lumajang Kabupaten Lumajang yang berjumlah 30 orang. Kegiatan diawali dengan tahap pemberian materi, praktik, dan diakhiri dengan evaluasi.

1. Tahap pemberian materi

Selama berlangsungnya kegiatan, peserta antusias mendengarkan materi yang disajikan karena presentasi dibuat semenarik mungkin bagi usia anak. Penyuluhan dilaksanakan dengan 3B 
(Bermain, Bernyanyi, Bercerita) selama 120 menit yang terbagi dalam 30 menit penyampaian materi, 30 menit praktik senam dan gerakan menyanyi bersama, serta 60 menit untuk diskusi dan tanya jawab. Pada saat penyuluhan, disampaikan:

a. konsep underwear rules yang perlu disampaikan kepada anak yang diaplikasikan melalui PANTS (Privates are private, Always remember your body belonging to you, No means no, Talk about secrets that upset you, Speak up, someone can help),

b. jenis sentuhan yang meliputi:

1) sentuhan boleh: menyentuh dari bahu ke atas atau lutut ke bawah, dan dilakukan dengan kasih sayang. Bagian ini boleh disentuh oleh teman atau sahabat sejenis.

2) sentuhan membingungkan: menyentuh badan dari bahu sampai atas lutut, dan dilakukan dengan kasih sayang dan nafsu. Pada bagian ini, keluarga yang boleh menyentuh.

3) sentuhan yang tidak boleh: bila seseorang menyentuh bagian badan yang ditutup pakaian renang, menyentuh paha, dada, dan bagian dekat kemaluan. Bagian ini hanya diri sendiri yang boleh menyentuh.

c. Tindakan yang harus dilakukan, bagaimana bereaksi dan bagaimana mencari bantuan.

Kegiatan pengabdian ini mendapatkan sambutan hangat dari peserta. Hal ini terbukti dengan banyak peserta yang mengajukan pertanyaan, tidak hanya dari santri tetapi juga dari guru TPQ Al Ihsan, orang tua santri, dan pihak RW 27 Kelurahan Tompokersan. Penyampaian materi yang menarik serta atraktif (video, gerakan dan menyanyi bersama) juga membuat anak menikmati dan tidak bosan terhadap penyuluhan yang diberikan.

\section{Tahap Praktik}

Tahap praktik dilakukan bekerjasama dengan guru TPQ untuk mengingatkan anak secara rutin, dan dengan orang tua untuk mengingatkan anak selama di rumah.
3. Tahap Evaluasi

Pada tahap evaluasi, $73 \%$ santri TPQ masih memiliki pengetahuan yang cukup tentang Underwear Rules. Tingkat pengetahuan kurang hanya terjadi pada $27 \%$ santri yang umumnya berasal dari kelompok umur 4-6 tahun. Hal ini terjadi karena pada umur 4-6 tahun, pemahaman anak lebih mudah dalam bentuk visual dan perlu pengulangan. Oleh karena itu penyampaian materi dalam bentuk video/gambar serta sering mempraktikkan gerakan-gerakan boleh dan tidak boleh dapat mempercepat proses pemahaman anak.

\section{SIMPULAN}

Dalam upaya menurunkan angka kejadian kekerasan seksual pada anak, maka dapat dilakukan tindakan salah satunya melalui penyampaian informasi atau pendidikan tentang Program Underwear Rules. Pendidikan kesehatan ini merupakan salah satu cara menyebarluaskan informasi kepada khalayak umum, salah satunya dilakukan di TPQ Al Ihsan RW 27 kelurahan Tompokersan, Kecamatan Lumajang, Kabupaten Lumajang. Kegiatan ini dihadiri oleh santri TPQ sebanyak 30 orang. Kegiatan ini dapat berlangsung secara tertib dan baik tanpa mengalami hambatan berarti.

\section{SARAN}

Perlu adanya kegiatan yang sejenis secara berkala pada masyarakat sekitar, dengan cakupan yang lebih luas (misalnya dengan sasaran pada pengajian ibu PKK, dan sejenisnya). Pada kegiatan pengabdian masyarakat selanjutnya disarankan menggunakan metode yang sama, lebih banyak mempraktikkan isi materi sehingga materi yang disampaikan dapat selalu diingat, atau disesuaikan dengan klasifikasi peserta seperti usia dan tingkat pendidikan anak

\section{DAFTAR PUSTAKA}

Hurairah, Abu. (2012). Kekerasan Terhadap Anak. Bandung: Nuasa Press

Justicia, Risty. (2016). Program Underwear Rules untuk Mencegah Kekerasan Seksual pada Anak Usia Dini. Jurnal Pendidikan Usia Dini Vol. 9 Edisi 2, November 2016 http://journal.unj.ac.id/unj/index.php/jp 
ud/article/view/3502/2508sitasi

tanggal 20 April 2018

Noviana, Ivo. (2015). Kekerasan Seksual terhadap Anak: Dampak dan Penanganannya.

https://media.neliti.com/media/publicat ions/52819-ID-kekerasan-seksual-

terhadap-anak-dampak-d.pdf sitasi tanggal 20 April 2018

Paramastri, Ira, dkk. (2010). Early Prevention Toward Sexual Abuse on Chlidren. Jurnal Psikologi Vol. 37, No. 1, Juni 2010, Hal. 1-12. https://journal.ugm.ac.id/jpsi/article/vi ew/7688/5955sitasi tanggal 20 April 2018

Parenting Indonesia. (2015). Underwear Rule Untuk keselamatan Anak. http://www.parenting.co.id/usiasekolah/underwear+rule+untuk+kesela matan+anak sitasi tanggal 20 April 2018

Pittkof, Evan . Protecting your Child By Talking About Growth,2008.

Probosiwi, Ratih dan Daud Bahransyaf. Pedofilia dan Kekerasan Seksual: Masalah dan Perlindungan terhadap Anak.

https://media.neliti.com/media/publicat ions/52836-ID-pedofilia-dankekerasan-seksual-masalah.pdfsitasi tanggal 20 April 2018

Santrock, John W., (2006),Life-Span Development, Perkembangan Hidup Jilid 1. Alih Bahasa Juda Damanik. Jakarta: Erlangga. 